\title{
O ASSÉdIO MORAL NA ADMINISTRAÇÃO PÚBLICA: DA RESPONSABILIDADE DO ESTADO PARA A EFETIVIDADE DAS AÇÕES PÚBLICAS PREVENTIVAS
}

\author{
Leonel Pires Ohlweiler ${ }^{1}$
}

\begin{abstract}
Resumo
O presente artigo investiga a responsabilidade extracontratual do Estado por assédio moral quando a vítima de danos é o servidor público, exposto a práticas que se prolongam no tempo e violam direitos de personalidade, bem como a necessidade de ações públicas de prevenção. $\mathrm{O}$ estudo utiliza a metodologia de pesquisa bibliográfica e jurisprudencial. As competências administrativas somente podem ser exercidas respeitando a autonomia dos servidores públicos. Os direitos fundamentais e a dignidade humana também determinam a compreensão do dever de indenizar da Administração Pública e das ações administrativas de prevenção, a partir do Estado Democrático de Direito e do fenômeno da constitucionalização. O assédio moral configura-se por ação ou omissão ilegítima que viola a dignidade e influencia o cotidiano das relações entre servidores e autoridades hierárquicas. A jurisprudência já examinou diversos casos de indenização de danos por assédio moral, mas ainda há incerteza em relação às indicações normativas suficientes para configurá-lo. O assédio moral, horizontal ou vertical, praticado no âmbito do serviço público determina o pagamento de indenização por danos patrimoniais ou morais, de caráter biológico ou existencial. A Administração Pública deve agir preventivamente ao assédio moral, por meio da modificação dos paradigmas tradicionais e de comissões paritárias.
\end{abstract}

Palavras-Chave: Assédio Moral; Administração Pública; Dignidade Humana; Jurisprudência; Prevenção.

\section{INTRODUÇÃO}

A responsabilidade extracontratual do Estado configura-se como instituto de grande relevância para a democratização da Administração Pública, pois sua história institucional representa o constante progresso de construção da cidadania. Nesse aspecto, o Constitucionalismo Contemporâneo, como será examinado, traz perspectivas importantes, impondo repensar o tema a partir de uma Teoria do Estado adequada para lidar com as complexidades de um Direito Administrativo como no Brasil, marcado pela prática patrimonialista e a consequente arbitrariedade nas relações entre os servidores e o ente público.

\footnotetext{
${ }^{1}$ Mestre e Doutor em Direito. Professor de Direito Administrativo na Graduação do Unilasalle e do Mestrado vol.09, $\mathrm{n}^{\circ}$. 03, Rio de Janeiro, 2016. pp. 1294 
O debate sobre ações ou omissões ilegítimas exige a discussão da própria Teoria das Fontes na qual a Constituição assume onipresença, normatizando o conjunto das práticas dos agentes públicos. Com efeito, o processo de compreensão de novas questões que surgem também exige uma diferenciada Teoria da Interpretação, assumindo cada vez mais relevância a construção de indicações capazes de obstaculizar discricionariedades ilegítimas.

É com tal cenário que a figura do assédio moral cada vez mais assume relevância no horizonte de sentido das relações jurídico-administrativas, pois o cidadão ocupa papel de centralidade, de legítima justificação do exercício dos poderes da Administração Pública. As competências administrativas direcionam-se para concretizar o dever de bem administrar a coisa pública; adquirindo relevância prerrogativas funcionais como a hierarquia e a disciplina. No entanto, o regime administrativo diferenciado não pode divorciar-se, por exemplo, do caráter deontológico do inciso III do artigo $1^{\circ}$ da Constituição Federal, impondo-se o dever de cuidado, respeito, autonomia, e liberdade aos servidores públicos. A dignidade humana configura-se como conceito interpretativo, ou seja, sobre o qual as pessoas controvertem e compartilham, exigindo duplo esforço hermenêutico para reconstruir sua história institucional, de modo a resolver casos, sem cair em concepções moralistas ou marcadas pela subjetividade.

$\mathrm{O}$ assédio moral releva-se assim como conceito interpretativo em permanente debate no âmbito do Direito Administrativo, com precedentes importantes e capazes de revelar o grau de proteção constitucional fundada na dignidade humana. No entanto, o autêntico Estado Democrático de Direito e a própria constitucionalização da responsabilidade do Estado, exigem laborar com o exercício das competências administrativas voltadas para a prevenção do assédio moral. Trata-se, como será examinado, de noção oriunda de discussões nos campos da sociologia e psicologia do trabalho, mas compartilhada aqui como meio de salvaguardar os direitos de personalidade dos servidores públicos de práticas sistemáticas e constantes que o colocam em situação de discriminação, desrespeito ou violação da liberdade.

O presente estudo é o início da pesquisa, não apenas com o propósito de melhor identificar o tema do assédio moral na Administração Pública, alguns desdobramentos, mas de contribuir com o necessário olhar hermenêutico, com a perspectiva da constitucionalização do Direito Administrativo e de construir a cultura preventiva por meio de ações públicas. Utilizouse como metodologia a pesquisa doutrinária e jurisprudencial. Na primeira parte do estudo, debate-se a relevância da dignidade humana no regime jurídico dos servidores públicos, com destaque para o dever de a Administração Pública respeitar a importância objetiva da autonomia, liberdade e dignidade do servidor. Após, a investigação volta-se para a 
responsabilidade extracontratual do Estado, mas debatida no horizonte de sentido do Constitucionalismo Contemporâneo, referência importante para problematizar o paradigma dominante sobre o tema. Na terceira parte, o assédio moral é discutido, especialmente em relação às consequências para o regime jurídico dos servidores públicos, possibilitando a releitura de algumas prerrogativas da Administração Pública, destacando-se a importante decisão italiana do Tribunal di Tempio Pausania, além de exemplos de casos examinados em tribunais pátrios sobre o dever de indenização por danos oriundos do assédio moral, o que é discutido logo a seguir. Por fim, coordenando as indicações doutrinárias com os exemplos de casos de responsabilidade extracontratual do Estado, ainda que de modo inicial, discute-se a compreensão do assédio moral em suas fases e de como podem ser desenvolvidas iniciativas relacionadas com ações públicas de caráter preventivo. O tema, portanto, é capaz de suscitar grandes debates, especialmente no Direito Administrativo, no qual ainda não existem muitas investigações específicas.

\section{O REGIME JURÍdico DOS SERVIDORES PÚBLICOS E A DIGNIDADE HUMANA: PROJEÇÕES HERMENÊUTICAS.}

A discussão sobre o dever de indenizar do Estado, em virtude da prática de assédio moral no serviço público, remete para o debate sobre a importância do princípio da dignidade humana no Direito Administrativo e, de forma mais específica, no regime jurídico dos servidores públicos. As peculiaridades sobre a relevância do tema são destacadas por Jesús González Pérez ao mencionar que as possibilidades de violação da dignidade humana crescem no Direito Administrativo, na medida em que as competências configuram manifestação última do poder coercitivo da Administração (GONZÁLEZ PÉREZ, 2011, p. 199). Não se pretende aqui retomar a polêmica doutrinária sobre os diversos fundamentos e significados da dignidade humana, mas sempre é relevante não olvidar o contributo de Kant, cujo labor filosófico coloca o homem no centro da elaboração do conhecimento, bem como destaca a impossibilidade moral de considerá-lo meio para os outros, pois é um fim em si mesmo, eis que é um ser racional, conforme refere de forma explícita na "Fundamentação da Metafísica dos Costumes":

Ahora yo digo: el hombre, y en general todo ser racional existe como fin en si mismo, no solo como médio para usos cualesquiera de esta o aquella voluntad; debe en toda sus acciones, no sólo las dirigidas a sí mismo, sino las dirigidas a los demás seres racionales, ser considerado siempre al mismo tiempo como fin. (KANT, 2005, p. 116).

Também, na esteira do pensamento do autor, a pessoa assim é chamada porque sua natureza funciona como elemento de distinção, no sentido de que como fim em si mesmo, não se pode utilizá-la como meio e, portanto, limita-se todo capricho, erigindo-se como digna de vol.09, nº. 03, Rio de Janeiro, 2016. pp. 
respeito. (KANT, 2005, p. 116) ${ }^{2}$. Muito embora as diversas críticas que são formuladas à fundamentação de Kant, há efetivamente questões importantes na sua teorização, como a negação de objeto para o homem, bem como a circunstância segundo a qual aquele que viola os direitos do homem, o utiliza como simples meio.

O respeito que o homem deve ao outro, a partir de Kant, não é algo a ser imposto pela violência, mas "situado, naturalmente, em termos de conteúdo, a meio caminho entre um dever jurídico e outro dever de virtude, o do amor ao próximo. " (SEELMAN, 2005, p. 46). O homem, com efeito, seria não apenas dotado de razão e de vontade, mas capaz de atuar sob o império da liberdade. Segundo Gregório Peces-Barba Martinez "la concepción formal de Kant, que basa la dignidad en la autonomia como postulado de la razón, tiene el gran valor de conectar dignidad, libertad, autonomía y moralidad, edifício que desde entonces se mantendrá como explicación básica de esta dignidad humana." (MARTINEZ, 2003, p. 57).

A concepção kantiana de dignidade humana exerceu grande influência no modo como o Direito realizará a leitura do tema. Um bom exemplo é o texto de Ignácio Gutierrez Gutiérrez sobre a matéria, destacando a interdição da instrumentalização do homem como algo inerente à dignidade humana. (GUTIERREZ, 2005). A partir daí surgem inúmeros entendimentos sobre o significado da expressão dignidade humana.

Considerando outra perspectiva ${ }^{3}$, ultrapassando-se a questão da dignidade do homem fundada na razão, compreende-se a importância de superar a vinculação ao fundamento de caráter metafísico, vislumbrando a pessoa como homem formador de mundo, como alude Ernildo Stein (STEIN, 2003, p. 16), cujo acesso somente ocorre por meio da linguagem. Na medida em que a linguagem é constitutiva de mundo exige-se a postura do diálogo, sendo importante, para a dignidade do homem, considerar que habita o mundo com os outros. Tratase de condição existencial que remete para a necessidade de adotar o modo de ser com respeito e Cuidado, pois as relações intersubjetivas nas quais o homem acontece deverão desenvolverse de modo a impedir que ocorram práticas capazes de velar os sentidos de humanidade partilhados ao longo da construção do Estado Constitucional. Esse olhar da dignidade parte do pressuposto trabalhado pelo Constitucionalismo Contemporâneo de que fala Lenio Luiz Streck (STRECK, 2012), sendo importante destacar que o princípio da dignidade humana não pode

\footnotetext{
${ }^{2}$ Kant refere o seguinte imperativo: "obra de tal modo que uses la humanidad, tanto en tu persona como en la persona de cualquier outro, siempre como un fin al mismo tiempo y nunca simplemente como un médio." (KANT, 2005, p. 116).

${ }^{3}$ Os pressupostos construídos pela Nova Crítica do Direito de Lenio Luiz Streck (STRECK, 2013 e 2014), um dos autores responsáveis pela problematização do pensamento de Martin Heidegger e Hans-Georg Gadamer no Direito, são adotados com a perspectiva de contribuir para um olhar diferenciado sobre o tema investigado.
} vol.09, n. 03, Rio de Janeiro, 2016. pp. 
constituir-se em espécie de álibi hermenêutico (STRECK, 2012, p. 40), para utilizar a expressão do autor, de modo a autorizar decisões carregadas de subjetividade, no sentido de arbitrárias/discricionárias. Conforme será examinado, um dos modos de combate ao assédio moral na Administração Pública é exatamente a compreensão das competências administrativas como integradas no conjunto de princípios com os quais deve manter coerência.

O princípio ora em debate, portanto, não retira seu conteúdo de instâncias metafísicas, como natureza, religião ou razão, mas do modo de ser das relações intersubjetivas existentes na moralidade política da comunidade, e das indicações normativamente institucionalizadas, o que determina a impossibilidade de construir-se o sentido de dignidade a partir da livre apreciação do aplicador (STRECK), pois é fundamental na compreensão aquilo que foi erigido, vivenciado como dignidade na comunidade política do Estado Democrático de Direito. A partir do contributo de Ronald Dworkin, é crível dizer que dignidade humana constitui-se como conceito interpretativo, quer dizer, sobre os quais as pessoas controvertem e compartilham como atores em práticas políticas. Constantemente o conceito é reinterpretado, de modo a criar as condições de possibilidade para dar continuidade a tais práticas primando pela coerência e integridade. $\mathrm{O}$ aludido conceito é construído com determinado propósito, um sentido que orienta e condiciona sua própria compreensão:

Em minha opinião, o conceito doutrinário de direito funciona como um conceito interpretativo, pelo menos em comunidades políticas complexas. Compartilhamos esse conceito como atores em práticas políticas complexas que exigem que interpretemos estas práticas a fim de decidir a melhor maneira de dar-lhes continuidade, e utilizamos o conceito doutrinário de direito, para apresentar nossas conclusões. Para elaborar o conceito, atribuímos valor e propósito à prática e formulamos concepções sobre as condições de veracidade das afirmações particulares que as pessoas fazem no contexto da prática, à luz dos propósitos e valores que especificamos. (DWORKIN, 2010, p. 19).

A normatividade do princípio constitucional da dignidade humana não se obtém com indicações abstratas e de caráter metafísico, mas percorrendo o longo caminho da tradição partilhada na comunidade política, problematizando as próprias consequências do advento do Constitucionalismo (STRECK, 2012, p.57). A dignidade humana é dotada na sua gênese do que se pode denominar de sentido histórico, com o qual os agentes públicos devem dialogar e justificar as decisões administrativas. É elucidativo o entendimento de Ingo Wofgang Sarlet sobre dignidade humana, após percuciente análise de uma perspectiva jurídico-constitucional:

Assim sendo, temos por dignidade humana a qualidade intrínseca e distintiva reconhecida em cada ser humano que o faz merecedor do mesmo respeito e consideração por parte do Estado e da comunidade, implicando, neste sentido, um complexo de direitos e deveres fundamentais que assegurem a pessoa tanto contra todo e qualquer ato de cunho degradante e desumano, vol.09, $\mathrm{n}^{\circ}$. 03, Rio de Janeiro, 2016. pp. 
como venham a lhe garantir as condições existenciais mínimas para uma vida saudável, além de propiciar e promover sua participação ativa e coresponsável nos destinos da própria existência e da vida em comunhão com os demais seres humanos, mediante o devido respeito aos demais seres que integram a rede da vida. (SARLET, 2011, p.73).

Como mencionado, a questão da dignidade humana, considerando as condições de possibilidade de compreensão, é altamente complexa e foge da finalidade específica deste estudo aprofundar o debate, pois se pretende focar a discussão nos desdobramentos do artigo $1^{\text {o }}$, inciso III, da Constituição Federal no regime jurídico dos servidores públicos, sempre com o olhar hermenêutico. Trata-se de princípio fundamental para o exercício das competências administrativas, mas na acepção de fundar algo, de indicar condições de possibilidade para que a Administração Pública exerça sua atividade voltada para salvaguardar no caso concreto a autonomia, o respeito, a liberdade e o cuidado com os servidores públicos. Não se pode olvidar que a Administração Pública brasileira deve fundar-se ontologicamente para instituir o Estado Democrático de Direito, inclusive nas relações com os servidores públicos. Sem aderir totalmente ao entendimento de Ronald Dworkin, no livro "Justiça para Ouriços", há um ponto importante debatido pelo autor sobre a dignidade humana relacionar-se hermeneuticamente com as questões do respeito e da autenticidade (DWORKIN, 2012, p. 211), bem como a circunstância de que tem sido distorcida, em virtude de utilizações abusivas, muitas vezes para simplesmente conferir carga emocional ao debate. Assim como em relação a todos os cidadãos, o Poder Público tem a obrigação, como refere Ronald Dworkin, de tratar os servidores públicos com igual preocupação e respeito (DWORKIN, 2012, p. 330). É claro que tais indicações abstratas não fogem daquilo que o autor refere diversas vezes: o conceito de dignidade é interpretativo, impondo-se a interpretação com base nas práticas da comunidade política para indicar as ações que caracterizam violação. Outrossim, a melhor concepção de dignidade será aquela que no caso conseguir integrar-se ao conjunto de todos os outros princípios da Administração Pública, pois não há dignidade em si, mas como conceito interpretativo, apoiase em outros conceitos interpretativos, integrando-se na rede de sentido sobre o modo mais adequado constitucionalmente de construir as relações entre Administração e servidores públicos.

Os poderes administrativos, inclusive os decorrentes da hierarquia e disciplina, somente justificam-se na medida em que promoverem indicações construídas historicamente e contextualizados no Estado Constitucional. Os atos administrativos, mais do que meras declarações do Estado, são atos de interpretação e a dignidade humana funciona como barreira de sentido, devendo necessariamente ingressar no processo de "applicatio" (GADAMER, 1993, p. 378). Logo, não há ato administrativo sem compreensão hermenêutica. Similares vol.09, n. 03, Rio de Janeiro, 2016. pp. 
repercussões poderão ser examinadas, o que foge aos propósitos deste breve estudo, relativamente aos direitos sociais dos servidores, processo administrativo disciplinar, deveres funcionais, etc. No entanto, é sempre válida a advertência de Ronald Dworkin, deve-se ter a preocupação de evitar os abusos de linguagem e as distorções de sentido quando se fala de dignidade humana.

Portanto, o texto do inciso III do artigo $1^{\circ}$ da Constituição Federal não deve ser compreendido imerso apenas no âmbito da lógica-formal, pois, como bem destacou Ernildo Stein:

...sabemos que os conceitos sempre têm mais atrás de si do que simplesmente serem funções, ou serem signos. Eles vêm carregados por elementos de valor, de validade, e este caráter de valor ou validade é que faz com que os conceitos não sejam simplesmente abstratos, todos eles formais e abstratos, mas faz com que eles tenham uma certa carga valorativa. (STEIN, 2004, p. 114).

Laborar com a dignidade humana no Direito Administrativo exige por parte dos operadores a justificação dos seus elementos de referência, da história institucional, do sentido que é construído no mundo da vida do Direito, proibindo utilizações injustificadas ou arbitrárias da dignidade, divorciadas hermeneuticamente desta carga de sentido. Por outro lado, não há como, “a priori”, fundar metafisicamente um discurso objetificador, mas apenas indicar elementos de sentido, até porque não se pode fazer tudo no Direito Administrativo com a bandeira da dignidade humana ${ }^{4}$. No próximo item, a dignidade humana será considerada como referência hermenêutica fundamental para compreender o assédio moral, objeto deste estudo sobre a responsabilidade extracontratual do Estado pela prática do assédio moral no serviço público e das ações públicas de prevenção.

\section{A CONSTITUCIONALIZAÇÃO DA RESPONSABILIDADE EXTRACONTRATUAL DO ESTADO.}

O tema sobre a responsabilidade extracontratual do Estado não é novo no âmbito do Direito Administrativo, mas é resultado do histórico processo de construção da disciplina e da afirmação dos direitos dos cidadãos. No entanto, ainda é importante destacar as influências da constitucionalização das relações entre cidadãos e Administração Pública sobre o dever de indenizar do Poder Público, especialmente a partir do chamado Constitucionalismo

\footnotetext{
4 Com relação à dignidade humana no Direito Administrativo, refere Jesús González Pérez: "Es incuestionable que cualquiera que seja la finalidade perseguida por la Administración, cualquiera que sea la forma de actuación y cualquiera que sea la realidade social sobre que recaiga, há de respetar como algo sagrado e inviolable la dignidade de la persona. Y algo más, todos e cada uno de sus actos han de estar informados por este valor esencial de nuestro Ordenamiento. No es necessário que así se establezca vol.09, nº. 03, Rio de Janeiro, 2016. pp. 
Contemporâneo, ou seja, deve-se vislumbrar o dever do Estado com o olhar de profunda democratização do Direito Administrativo, no âmbito de uma Constituição de caráter normativo e não meramente de documento político, como bem refere Lenio Luiz Streck:

Nesta medida, pode-se dizer que o Constitucionalismo Contemporâneo representa um redimensionamento na práxis político-jurídica, que se dá em dois níveis; no plano da teoria do Estado e da Constituição, com o advento do Estado Democrático de Direito, e no plano da teoria do direito, no interior da qual se dá a reformulação da teoria das fontes(a supremacia da lei cede lugar à onipresença da Constituição). Na teoria da norma (devido á normatividade dos princípios) e na teoria da interpretação(que, nos termos que proponho, representa uma blindagem às discricionariedades e aos ativismos). (STRECK, 2012, p.37).

A constitucionalização, portanto, é compreendida como constante transformação do fenômeno jurídico, ocasionando a impregnação total pelas normas constitucionais, conforme destaca Ricardo Gaustini (GUASTINI, 2003, p. 49) e não como ato isolado. Obviamente este não é o espaço apropriado para debater as profundas mudanças de paradigmas ocasionadas pela constitucionalização do Direito Administrativo ${ }^{5}$, sendo imperioso referir a observação de Harmut Maurer sobre as relações entre Direito Administrativo e a Constituição: "Ela conduziu a transformações profundas, à recusa de concepções jurídicas tradicionais e ao reconhecimento de novos institutos jurídicos." (MAURER, 2006, p. 21) salientando, inclusive, o papel importante que a doutrina e jurisprudência assumiram, ora com postura dirigente e, até mesmo, por vezes, de ruptura decisiva. Como bem destaca Hans J. Wolf, a Constituição tem que ser capaz de regular a estrutura jurídica fundamental e fixar os seus limites no sentido de um "genetic code". (WOLF, 2006, p.193). De outra banda, a permanente dependência constitucional da Administração surge no fato de toda decisão administrativa ser potencialmente decisão constitucional.

Estabelecidas algumas pré-compreensões, não se pode olvidar que no caso brasileiro o dever de a Administração Pública indenizar encontra substrato normativo no próprio texto da Constituição Federal, artigo $37, \S 6^{\circ}$. Segundo o dispositivo, as pessoas jurídicas de direito público e as de direito privado prestadoras de serviço público responderão pelos danos que seus agentes, nessa qualidade, causarem a terceiros, assegurado o direito de regresso contra o responsável nos casos de dolo ou culpa.

$\mathrm{Na}$ medida em que compreender exige a tarefa constante de desvelar novas possibilidades, a compreensão da responsabilidade extracontratual do Estado impõe permanente postura de diálogo hermenêutico com a tradição, para utilizar o contributo de

expressamente al regular cada una de las matérias administrativas.” (GONZÁLEZ PÉREZ, 2011, p. 202).

${ }^{5} \mathrm{O}$ tema é amplamente debatido por Juarez Freitas (FREITAS. 2013), Patrícia Baptista (BAPTISTA, 2003) e Gustavo Binenbojm (BINENBOJM, 2014). 
Hans-Georg Gadamer (GADAMER, 1993), ao defender a tese segundo a qual a tradição é companheira de diálogo. Quando se fala de responsabilidade extracontratual do Estado é sempre válido bem dimensionar que o instituto, ao longo de sua evolução, representou a superação do pensamento da irresponsabilidade ${ }^{6}$ do Poder Público para a consagração da ideia de Estado de Direito ${ }^{7}$. Daí a observação interessante de Eduardo García de Enterría quando menciona que a responsabilidade patrimonial dos entes públicos, junto com a legalidade, seriam os dois grandes suportes estruturais do Direito Administrativo, "cuyo equilibrio, amenazado siempre por el peso inicial de las prerrogativas del Poder, depende, justamente, de su correcto juego." (GARCIA DE ENTERRÍA, 1995, p. 355). Tais entendimentos são relevantes quando da análise do princípio da responsabilidade do Estado, pois sempre deverá haver uma espécie de compreensão mediada pelos princípios constitucionais dos diversos elementos fáticos e jurídicos do caso concreto.

Relativamente à incidência dos direitos fundamentais, a responsabilidade extracontratual do Estado precisa ser repensada a partir de tal paradigma, pois a aplicação do artigo $5^{\circ}, \S 1^{\circ}$, da Constituição Federal, é ilustrativa da necessidade de contrapor as ações e omissões capazes de gerar o direito à indenização com os direitos fundamentais, plenamente oponíveis ao Poder Público. Como refere Juarez Freitas:

Eis argumento-chave a favor de uma acepção alargada: o sistema brasileiro consagra a eficácia direta e imediata dos direitos fundamentais, oponíveis perante o Poder Público. Segundo tal raciocínio, as condutas comissivas e omissivas, uma vez presente o liame causal, serão ilícitas em sentido amplo, por agredirem direitos fundamentais, inclusive quando da execução equivocada de lei genuína. (FREITAS, 2006, p. 170-171).

É crível dizer que os direitos fundamentais são cruciais para determinar a compreensão do instituto em exame, não mais a partir da ideia de legalidade, mas da concepção de violação da juridicidade (constitucionalidade). Como refere Paulo Otero:

A juridicidade administrativa traduz uma legalidade mais exigente, revelando que o poder público não está apenas limitado pelo Direto que cria, encontrando-se também condicionado por normas e princípios cuja existência e respectiva força vinculativa não se encontram na disponibilidade desse mesmo poder. Neste sentido, a vinculação administrativa à lei transformou-se numa verdadeira vinculação ao Direito, registrando-se aqui o abandono de uma concepção positivista-legalista configurativa da legalidade

\footnotetext{
${ }^{6}$ Não se poderia falar em irresponsabilidade absoluta, pois o dever de indenizar alcançava determinadas esferas das atividades públicas mesmo em tempos mais remotos, como alude Sérgio Severo (SEVERO, 2009, p. 04). O autor acrescenta que a transição do regime de irresponsabilidade foi jurisprudencial, gradual e contemporânea nos ordenamentos jurídicos da família romano-germânica, apresentando algumas dificuldades no tratamento da matéria.

${ }^{7}$ Sobre o ponto, vale referir as observações de Alice Gonzáles Borges (BORGES, 2006, p. 19): "Nunca é demais enfatizar que a responsabilidade civil do Estado pela reparação dos danos que venha causar aos cidadãos-administrados, é um dos mais caros fundamentos do Estado de Direito, do qual é consequência lógica e inevitável".
} vol.09, n. 03, Rio de Janeiro, 2016. pp. 
administrativa, tal como resulta do entendimento doutrinal subjacente à

Constituição de Bona. (OTERO, 2003, p.15).

Mas, não se pode olvidar, os direitos fundamentais determinam a modificação do foco da responsabilidade extracontratual do Estado; não mais centrada sobre a Administração Pública e a ilicitude praticada e sim na existência do dano causado pelo exercício da função administrativa $^{8}$. A perspectiva preponderante passa a ser o cidadão, fruto da substantivação democrática das relações com o Poder Público, como menciona Pedro Machete, ao defender que a democratização da Administração Pública importa na centralidade do cidadão, ocasionando a juridicização da relação estabelecida, apresentando-se Estado e cidadão como titulares de direitos e obrigações recíprocas. (MACHETE, 2007, p. 444) ${ }^{9}$. Crucial, portanto, a partir dessa ótica, é problematizar sobre a existência do que se convencionou chamar de dano injusto, sendo preferível a denominação dano ilegítimo. De qualquer sorte, o foco de atenção não é tanto a Administração Pública, mas a circunstância de que o cidadão sofreu um dano ilegítimo, isto é "o dano será injusto quando, ainda que decorrente de conduta lícita, afetando aspecto fundamental da dignidade humana, não for razoável, ponderados os interesses contrapostos, que a vítima dele permaneça irressarcida." (MORAES, 2009, p. 179). Na tradição da responsabilidade extracontratual do Estado há muito se trabalha com as hipóteses de responsabilidade por atos lícitos, nas circunstâncias especiais em que o Estado, no exercício do seu poder administrativo, viola direitos dos cidadãos, admitindo-se a indenização com base na garantia equânime da repartição dos ônus provenientes de atos estatais lesivos (principio da igualdade), como destaca Celso A. Bandeira de Mello (BANDEIRA DE MELLO, 2009, p. 997).

No entanto, a partir da compreensão do tema por meio do Constitucionalismo Contemporâneo, é acertada a observação de Juarez Freitas, no sentido da necessidade de ultrapassar esta dicotomia (FREITAS, 2006, p. 178-179). Considerando a ampla gama de construções teóricas no âmbito dos direitos fundamentais, para fins de concretizar algumas de suas influências no campo da responsabilidade do Estado, é relevante destacar a possibilidade jurídica de violação de direitos fundamentais como direitos de defesa (MENDES, 1998, p. 33) originar o dever de indenização, assim como a antijuridicidade decorrente de condutas omissivas que violem direitos fundamentais a prestações positivas (MENDES, 1998, p. 40),

\footnotetext{
${ }^{8}$ As reflexões aqui realizadas decorrem do plano de abordagem realizado por Caitlin Sampaio Mulhollan (MULHOLLAN, 2009), no âmbito da responsabilidade civil, bem como no trabalho de Maria Celena Bodin de Moraes (MORAES, 2009).

${ }^{9} \mathrm{O}$ autor sustenta a ideia de uma Administração Pública paritária, mas não no sentido de que cidadão e Poder Público estão em situação absolutamente igual, mas que as prerrogativas do Estado devem ser exercidas no âmbito do marco da relação jurídica, sempre legitimamente fundado em normas jurídicas, reconhecendo as posições constitucionais dos cidadãos.
} vol.09, nº 03, Rio de Janeiro, 2016. pp. 
sempre destacando a necessidade de compreensão proporcional das circunstâncias fáticas e jurídicas do caso concreto.

Outro aspecto relevante da constitucionalização reside no papel de destaque ocupado pela dignidade humana: (a) na qualificação jurídica dos danos ilegítimos, especialmente aqueles decorrentes de violação dos direitos de personalidade, como práticas administrativas discriminatórias ou que não respeitem as diferenças e as posições jurídicas dos cidadãos, além de danos oriundos de atos de tortura ou violação de garantias processuais; (b) relativamente à quantificação do valor de indenização por danos extrapatrimoniais, ensejando a compreensão proporcional com os demais direitos e interesses que estão em jogo em cada caso concreto e (c), por fim, a renovada compreensão do nexo causal, destacando-se sua ampliação e alargamento em situações peculiares ${ }^{10}$. Considerando o próximo item a ser debatido, a constitucionalização da responsabilidade do Estado implica a institucionalização no exercício das competências administrativas do especial dever de Cuidado, ou seja, na medida em que as relações entre Administração Pública e servidores públicos estrutura-se por meio de procedimentos de coerção, restrição de direitos e liberdades, a dignidade humana (artigo $1^{\circ}$, III, CF) determina aos agentes públicos assumirem a posição intersubjetiva de prevenção e precaução, sob pena do surgimento da antijuridicidade capaz de gerar o dever de indenização, especialmente em casos de assédio moral.

\section{A EFETIVIDADE DO DEVER DE INDENIZAR POR DANOS DECORRENTES DE ASSÉdIO MORAL NO SERVIÇO PÚBLICO.}

O regime jurídico dos servidores públicos, configurado como conjunto de direitos e deveres, também deve ser compreendido a partir do sentido do chamado Constitucionalismo Contemporâneo (STRECK, 2013), como já mencionado, ultrapassando-se o modo de ser patrimonialista que durante muito tempo foi característica marcante da Administração Pública brasileira, como destaca Cármen Lúcia Antunes Rocha (ROCHA, 1999, p. 117). Como aduz a atual ministra do Supremo Tribunal Federal deve-se entender em termos a afirmação segundo a qual o regime jurídico dos servidores público depende de uma decisão política do legislador, pois não há como vislumbrar o conteúdo de direitos e deveres dos servidores públicos fora da Constituição Federal:

Dito de outra forma, tem-se que o regime jurídico do servidor público tem a sua natureza determinada por um conjunto de elementos que se extraem do subsistema constitucional da Administração Pública e que advém do

\footnotetext{
${ }^{10}$ Sobre estes itens, relacionados à responsabilidade civil, ver MULHOLLAND (2009, p. 69-75). vol.09, nº. 03, Rio de Janeiro, 2016. pp.
} 
condicionamento desta em razão de seus fins, de sua personalidade e de sua competência. (ROCHA, 1999, p. 118).

A constitucionalização do regime jurídico de servidores públicos foi destacada por Miguel Sànchez Morón, no contexto do Direito Administrativo espanhol, quando, em monografia específica, refere a importância da democratização do Estado e a previsão da função pública na Constituição Espanhola, o que importa na distinção entre Governo e Administração. Essa última é chamada para cumprir uma função própria e institucional de servir os interesses gerais e com objetividade, livre de critérios dos partidos políticos, primando pela imparcialidade do funcionário no exercício de suas atribuições. (SÁNCHEZ MÒRON, 2008, p. 46). É em tal contexto que aduz a importância da proteção da dignidade no trabalho do funcionário, pois muito embora com conteúdo indefinido, exclui toda espécie de comportamentos vexatórios ou abusos por parte dos superiores, companheiros ou subordinados. Complementa Jesús González Pérez:

Realmente, la dignidad del cargo y de la función pública constituye algo muy distinto a la dignidad de la persona. Pero que el funcionário tiene derecho a que se le respete su dignidad personal es incuestionable. Derechos frente a los superiores, frente a los demás funcionarios - incluso los inferiores $-\mathrm{y}$ frente al administrados. (GONZÁLES PÉREZ, 2011, p. 204).

Relativo ao assédio moral, Alexandre Pandolpho Minassa sustenta:

Entende-se por assédio moral um processo malicioso que manipula a pessoa envolvida mediante o desprezo pela sua liberdade, dignidade e personalidade, com o único intuito de aumentar o poder do agressor por meio da pura eliminação de todos os obstáculos presentes no seu percurso até o topo. (MINASSA, 2012, p. 115).

Como menciona o autor, o assédio moral é designado por meio de diversas expressões, como harassment, bullying, whitleblowers, mobbing, sendo que essa última foi uma das primeiras expressões utilizadas, exatamente, para identificar a conduta agressiva dos animais reunidos em grupo e que expulsavam aquele considerado como intruso. Sobre o tema também vale a referência de Maria Gentile:

$\mathrm{Si}$ trata di un termine di largo uso in etiologia per descrivere il comportamento agressivo di un animale del branco nei confronti di un altro membro del grupo, oppure di un capo isolato, per allontanarlo. (...)

Il termine to mob deriva, a sua volta dall'espressione latina 'mobile vulgus', che indica il movimento della gentaglia che aggredisce qualcuno. Nella sua sinteticitá la locuzione inglese è apparsa in grado di descrivere quelle particolari forme di degenerazione dei rapporti interpersonali nell'ambito lavorativo, le quali si concretizzano in una sorta di aggressione sistematica posta in essere nei confronti di um soggetto, direttamente per opera del datore di lavoro o dei suoi preposti o anche da parte di colleghi della vittima medisima, che provocano un progressivo disadattamento lavorativo di quest'ultima. (GENTILE, 2009, p. 3). ${ }^{11}$

\footnotetext{
${ }^{11}$ No mesmo sentido refere Maria Bovino: "Più precisamente per mobbing s'intende una forma di violenza psicologica che si exercita sul posto di lavoro, attraverso gli attachi del datore di lavoro o degli stessi colleghi di lavoro." (BOVINO, 2012, p.02).
} 
No âmbito do serviço público, é conduta que afeta a dignidade do servidor público, repetindo-se por período de tempo e quando é direcionado com o intento de incidir sobre a vítima do assédio moral, no que tange aos aspectos de sua personalidade, como respeito, integridade psíquica, liberdade, autonomia, etc. $\mathrm{O}$ assédio moral é praticado pela Administração Pública com a finalidade de induzir condutas por parte do servidor-vítima consistentes em exoneração ou até requerimento de aposentadoria, na medida em que cria um ambiente de trabalho muito difícil de conviver, pois o servidor é exposto cotidianamente às tentativas de desestabilização emocional e profissional. (MINASSA, 2012, P. 129).

Muito embora não exista unanimidade entre os autores quanto aos requisitos necessários para configurar o assédio moral, destacam-se os seguintes: (a) o conflito deve desenvolver-se no ambiente de trabalho; (b) a ação ofensiva ocorre durante algum período de tempo, alguns meses; (c) desnível entre os antagonistas, encontrando-se a vítima em posição constante de inferioridade; (d) intenção de perseguição em relação à vítima do assédio moral como bem recorda Maria Gentile. (GENTILE, 2009, p. 07). ${ }^{12}$ De qualquer modo, condutas isoladas e que também são capazes de causar danos aos aspectos da personalidade do servidor público não configuram assédio moral.

O assédio moral pode ser praticado pelo superior hierárquico, quando se denomina como vertical, ou entre colegas, identificado como assédio moral horizontal, conforme Maria Bovino:

"Il mobbing verticale è quello gerarchico. In questo caso gli sono perpetrati dal datore di lavoro o dai dirigenti dell'azienda, verso uno o più dipendenti per constringerli a dare le dimissioni. Nella stragrande maggioranza dei casi gli altri colleghi stanno a guardare o per cosiddetto 'quieto vivere', o perché semmai sperano di trarne vantaggio professionalmente. Il mobbing verticale si articola in tanti comportamenti vessatori e continui, a volte subdoli, ma che a lungo andare, le stime parlando di 6 mesi -1 anno -,provocano una situazione di grave disagio psico-fisico nel soggeto mobbizzato." (BOVINO, 2012, p. 5-6).

Caracteriza-se, portanto, conduta reiterada do agente público, voltada para construir a situação de humilhação em relação à vítima do assédio, cujos atos ocasionam diversos

\footnotetext{
${ }^{12}$ A autora refere que a prática do "mobbing" desenvolve-se inicialmente com a individualização da vítima de assédio moral, com o começo de ataques contra a vítima, seguido por uma fase posterior em que se percebe o clima de tensão na relação laboral. Posteriormente, como terceira fase manifestam-se os primeiros sintomas psicossomáticos na vítima e que interferem no desenvolvimento de suas atividades, determinando a quarta fase que consiste nos equívocos perpetrados pela Administração Pública, incapaz de perceber as verdadeiras causas do baixo rendimento do servidor assediado, e, em alguns casos, inicia até procedimentos disciplinares. Como consequência, na quinta fase ocorre o agravamento dos sintomas psicossomáticos e que desencadeiam a sexta e última fase consistente na exclusão do mundo do trabalho (GENTILE _ , 2009, p.9). A questão será melhor examinada na última parte do estudo.
} 
transtornos na própria vida funcional e cotidiana do servidor e até influenciam no seu equilíbrio psicológico, prejudicando de forma direta ou indireta o exercício das atividades funcionais. Relativamente ao aspecto do requisito subjetivo, é importante assumir a postura de objetivação do assédio moral, inclusive para fins de responsabilidade do Estado no ordenamento constitucional brasileiro (artigo 37, $\S 6^{\circ}, \mathrm{CF}$ ). Com efeito, por exemplo, a exposição do servidor público à situação vexatória configura-se de modo objetivo, a partir do conjunto de ações ou omissões comprovadas, impondo-se mais a compreensão da relação intersubjetiva entre Administração Pública e servidor ou entre servidores públicos e sua caracterização como capaz de violar a dignidade humana, independente da intenção.

Tal linha de compreensão aproxima a prática do assédio moral com o tema da violação da dignidade do servidor, sendo que a dignidade aqui, conforme destacado, vislumbra-se como reconhecimento da importância objetiva da vida do servidor público, impondo-se à Administração o dever de não depreciar o valor da vida humana em todos os seus aspectos, como destaca Ronald Dworkin (DWORKIN, 2012, p. 295), pois como refere o jusfilósofo, nenhuma nação que permita a humilhação pode afirmar que reconhece uma concepção inteligível de dignidade humana.

Maria Gentile, ao examinar a tutela de proteção às vítimas de assédio moral, reflete sobre uma das primeiras sentenças que tratou do tema em relação à Administração Pública (GENTILE, 2009, p. 78) do Tribunal di Tempio Pausania, Sentenza n. 157/2003, na qual houve debate sobre as relações tensas entre servidora e administração, com a alegação de ser submetida a procedimento disciplinar por motivos fúteis, além de ter negada a possibilidade de trabalhar no desempenho específico de suas atividades de "agente di pubblica sicurezza", pois colocada para exercer as atividades em lugar separado dos serviços da polícia municipal, em uma espécie de porão (MASTINO, 2014).

$\mathrm{Na}$ medida em que o assédio moral configura-se por conduta de desrespeito que se prolonga no tempo, a sentença realizou a reconstrução da história institucional das relações entre a Administração Pública e a vítima do assédio moral, a fim de constatar a existência de procedimento ilegítimo, com o propósito de causar-lhe um dano, de marginalizar, discriminar, provocar um dano à saúde. Como em alguns casos examinados por Tribunais no Brasil, o assédio moral materializa-se por retirar o servidor público do exercício normal de suas atribuições. Por essa razão, como no caso julgado pelo tribunal italiano, houve análise detalhada das atribuições do cargo de "agente di pubblica sicurezza", destacando-se que tais atribuições, próprias do cargo, não estão na esfera de liberdade, de discricionariedade, mas exigem vínculo de respeito com o texto normativo que fixa as atribuições. É comum a prática 
do assédio moral quando o agente público hierarquicamente superior exerce a prerrogativa administrativa de modo a distanciar cada vez mais a vítima do normal exercício das funções próprias do cargo, o que contribui para enfraquecer as relações.

A decisão destaca com propriedade o procedimento de perseguição por parte do Prefeito no confronto com a servidora, indicado por meio de diversos confrontos, alguns disciplinares, mas outros não, que afetaram a personalidade da vítima, pois fundadas não em questões legítimas e disciplinares, mas em críticas genéricas sobre o seu caráter, fator determinante para a postura de isolamento, não apenas físico, mas moral, como consta de forma expressa na sentença, comprovando o tratamento discriminatório. Aqui há outro dado significativo sobre a prática do assédio moral: na medida em que se caracteriza por conduta continuada no tempo, há o crescente processo de deterioração moral da vítima, não apenas em relação ao superior hierárquico, mas relativamente aos seus próprios colegas.

Também vale a referência sobre a utilização das prerrogativas disciplinares e hierárquicas no processo de discriminação. $\mathrm{O}$ agente público autor do assédio moral, no intuito de colocar a vítima em tal situação, exerce as competências administrativas com motivações genéricas, no intuito de possibilitar ao menos a legitimidade formal. Com efeito, é importante a investigação substancial das condições fáticas e jurídicas, eis que o assédio materializa-se mediante desvio de finalidade. No entendimento de Maria Gentile, a hipótese de "mobbing" vertical se configura como violação das obrigações da Administração Pública de respeitar a personalidade do servidor, evitando comportamentos que, formalmente corretos, caracterizamse como forma de pressão ou de agir sobre a vítima. (GENTILE, 2014, p. 66).

Nesse intuito, em algumas hipóteses, o superior hierárquico decide inicialmente o próprio isolamento físico do servidor público, constituindo-se como tentativa de marginalizar e isolá-lo psicologicamente, como destacado na sentença proferida pelo Tribunal di Tempio Pausania. Como mencionado, algumas condutas, compreendidas de forma individual, talvez não sejam suficientes para compreender a prática do "mobbing", impondo-se vislumbrar a integridade dos comportamentos ou omissões administrativas, no sentido de reconstruir a história institucional voltada para perseguir o agente público, violando a dignidade.

$\mathrm{Na}$ medida em que a dignidade humana é um conceito interpretativo, deve-se destacar que possui caráter hermenêutico deontológico, ou seja, assume normatividade a capacidade de influenciar a própria concepção do exercício das competências administrativas, inclusive no exercício da prerrogativa de impor sanções disciplinares aos servidores públicos. Como refere Lenio Luiz Streck, em relação aos princípios jurídicos, "são eles os marcos que permitem a 
compreensão da história institucional do direito - por isso - eles expressam de modo complexo o momento hermenêutico do direito." (STRECK, 2012, p. 560).

O mesmo vale para o assédio moral, os diversos conceitos devem ser entendidos como conceitos interpretativos e muito mais do que definir o espaço semântico de compreensão, impõe-se discutir sobre sua aplicação no caso, a partir dos deveres de integridade e coerência. No entanto, nem toda violação da dignidade do servidor público importa prática do assédio moral. Aqui se exige da decisão judicial o dever de justificação, especialmente para demonstrar que o conjunto de atos praticados pelo agente público hierarquicamente superior distancia-se daquilo que deve ser vivenciado como ideal de vida boa em termos de relação jurídicaadministrativa com o servidor público. Outro ponto importante é que a prática prolongue-se no tempo, elemento crucial como inclusive destacado na citada sentença proferida pelo Tribunal di Tempio Pausania. O que caracteriza assédio moral não pode decorrer da esfera de subjetividade do julgador, mas originar-se da história institucionalizada pela doutrina e jurisprudência, guardando os deveres de integridade e coerência.

\section{O ASSÉDIO MORAL NA JURISPRUDÊNCIA: QUESTÕES HERMENÊUTICAS.}

Os casos de assédio moral na Administração Pública vêm sendo discutidos também pela jurisprudência pátria, especialmente no âmbito dos tribunais estaduais e em alguma medida pelo Supremo Tribunal Federal e Superior Tribunal de Justiça. Em relação a esses últimos, as dificuldades de encontrar precedentes remontam à estrutura recursal brasileira, com restrição decorrente da necessidade de violação direta da Constituição Federal, ou o aspecto de reexame da matéria probatória. De qualquer modo, por exemplo, no Supremo Tribunal Federal há decisão interessante proferida por ocasião do julgamento do AI 807909, Rela. Min. Cármen Lúcia, j. 25.08.2010, na qual manteve a decisão de origem. O caso versava sobre o tema do dever de indenizar. A sentença de primeira instância considerou que o Presidente de uma Câmara de Vereadores causou sofrimento e humilhações passíveis de indenização pecuniária. O Tribunal de Justiça do Espírito Santo manteve a decisão, referindo que estava configurada a ação do agente público no sentido de valer-se da superioridade hierárquica e no intuito de punir e desestabilizar psicologicamente o autor tratou o servidor público de maneira constrangedora.

Na jurisprudência do Superior Tribunal de Justiça há decisões recentes enfrentando o tema do assédio moral, mas em diversos casos, como aludido, esbarrando na impossibilidade de reexaminar a prova dos autos, nos termos da Súmula $n^{\circ} 07$ do STJ. De qualquer modo, é interessante destacar alguns julgamentos para indicar que a questão do assédio moral tem sido vol.09, n. 03, Rio de Janeiro, 2016. pp. 
debatida no âmbito dos tribunais estaduais e federais, com a dificuldade de caracterização em virtude do seu caráter reiterado e, via de regra, ausência de justificação relativamente aos requisitos para a configuração do "mobbing". No RESP $\mathrm{n}^{\circ}$ 1.3883.343-RJ, julgado em 04.08.2014, foi examinada decisão do TRF da $3^{\text {a }}$ Região, no qual o tribunal adotou o entendimento antes referido do assédio moral que decorre do abuso cometido contra o subordinado pelo superior hierárquico que, excedendo dos poderes, dispensa ao servidor tratamento incompatível com a dignidade, impondo-lhe rigor excessivo ou constrangimentos alheios aos interesses da Administração, mas exige a reiteração do tratamento ofensivo. Nesse caso prevaleceu o entendimento segundo o qual a mera interferência no exercício das atribuições não tem o condão de caracterizar abuso de poder do superior hierárquico, decisão mantida pelo STJ em virtude da impossibilidade de reexaminar a prova dos autos.

Outro julgado levado ao exame do STJ é oriundo do Tribunal de Justiça de Minas Gerais, ARESP $\mathrm{n}^{\mathrm{o}}$ 403799, j. 03.06.2014, no qual o tribunal de origem discutiu a caracterização de assédio moral, por omissão, na modalidade de assédio organizacional, mencionando que com o tempo o conceito tradicional de assédio moral revelou-se insuficiente para a compreensão da evolução da dinâmica das relações de trabalho, sendo que a doutrina desenvolveu o conceito de assédio organizacional, cujo objetivo é obstar condutas abusivas decorrentes das novas formas de organização do trabalho. No caso, o Estado, em virtude da má gestão institucional, deixou de fornecer condições mínimas de trabalho para os servidores, agindo de forma negligente, atraindo a responsabilidade pelos danos morais causados. Houve a condenação do ente público no TJMG, decisão mantida pelo STJ em razão da impossibilidade de reexaminar a prova dos autos. No julgamento do ARESP $n^{\circ} 479940$, julgado em 26.03.2014, o STJ, pelos mesmos motivos, manteve decisão do Tribunal de Justiça do Amapá que condenou agente público por improbidade administrativa em virtude da prática de assédio moral, consistente no remanejamento de pessoal sem motivação, por perseguição política, violando os princípios da legalidade, impessoalidade, probidade e boa-fé.

No julgamento monocrático do ARESP nº 331128, Min. Napoleão Nunes Maia Filho, j. 09.12.2013, o agravo interposto foi improvido, mantendo-se a decisão que negou seguimento ao recurso especial interposto pelo Município de Cabo de Santo Agostinho, condenado ao pagamento de indenização por assédio moral, caracterizado em virtude de a Administração Pública remover servidor público com caráter punitivo e sem motivação, com o objetivo de retaliações. Também versando sobre assédio moral na Administração Pública, o julgamento do ARESP 379656 em 27.09.2013, no qual prevaleceu a decisão do TJES que entendeu comprovado o assédio moral praticado por meio de perseguições e atitudes discriminatórias, vol.09, nº. 03, Rio de Janeiro, 2016. pp. 
causando na vítima humilhação e constrangimento, impondo-se o dever de indenizar. Por ocasião do julgamento do AREsp 344025, Min. Arnaldo Esteves Lima, j. 09.08.2013, negou-se provimento ao agravo, mantida decisão do TJMS que condenou o agente público por assédio moral, reconhecendo que houve comportamento com excesso dos parâmetros estabelecidos pelos princípios administrativos e da normalidade, consistente em reunião realizada para tratar de assuntos particulares do Chefe do Poder Executivo Municipal fora do Paço Municipal, com exposição do autor à situação vexatória.

No âmbito do STJ, destaca-se por último o recente julgamento do ARESP $n^{\circ}$ 778.125RS, Min. Herman Benjamin, 25.09.2015, quando examinou a tese de assédio moral de professora estadual, acusando a Diretora de Escola de perseguição, obrando os mais variados esforços para afastá-la dos quadros da instituição, caracterizando a prática do assédio moral, mantendo-se a improcedência dos pedidos, nos termos do exame de provas realizado pelo tribunal de origem, pois não houve prova de o Estado, por meio de seu agente público, ter agido fora dos parâmetros legais de sua competência.

O Tribunal de Justiça do Estado do Rio Grande do Sul julgou casos relevantes de assédio moral, não apenas para permitir identificar as circunstâncias fáticas ordinárias que ocorrem na Administração Pública e ensejam o assédio moral, mas para o debate sobre os requisitos de configuração. Como exemplo, na Apelação Cível nº 70056192321, Desa. Íris Helena Medeiros Nogueira, 09.04.2014, discutiu-se o caso em que servidor público, motorista do Município de Nova Hartz, requereu o pagamento de indenização por danos morais, em virtude de ter sofrido assédio moral por perseguição política. Conforme alegou, quando o Município começou a ser administrado por partido político diverso, iniciou-se o assédio moral, eis que registrava o seu ponto e ficava sentado em um banco no interior da repartição. Durante o período ficou sem qualquer trabalho, situação que perdurou por quatro anos. O exame da justificação utilizada permite as seguintes conclusões: (a)houve prova suficiente de que mesmo titular de cargo de provimento efetivo, motorista de caminhão, o Município o impediu de exercer as atribuições do cargo, pois recebeu ordens para permanecer sentado em um banco localizado na Secretaria Municipal de Obras; (b)a determinação administrativa foi praticada com a intenção de lhe impor castigo, pois era filiado a partido político diverso do Prefeito Municipal, bem como desestabilizar o servidor perante os colegas humilhando-o; (c)caracterizada no caso concreto a conduta discriminatória prolongada no tempo, eis que perdurou durante o período de quatro anos e (d)tal ação administrativa ultrapassou os limites do exercício discricionário da competência administrativa. 
No julgamento da Apelação Cível no 7056565740, Des. Miguel Ângelo da Silva, 29.10.2014, foi analisada a prática do assédio moral por meio da utilização dos poderes hierárquico e disciplinar. Os autores da ação de indenização proposta contra o Município alegaram a prática do assédio consistente na abertura de diversas sindicâncias de forma sistemática e reiterada, por largo período de tempo, motivadas por atos de perseguição e discriminação praticados por superiores hierárquicos, além de apelidos pejorativos utilizados. Ambos trabalhavam em Posto de Saúde e o conjunto probatório comprovou a prática humilhante com apelidos, em virtude do excesso de peso da servidora e da opção sexual do servidor. Do precedente podem ser retiradas indicações importantes sobre o assédio moral: (a)o assédio moral configurou-se em razão do excesso de poder disciplinar com a instauração de sindicâncias e punições antecipadas e subjetivas, além da disseminação de uma imagem negativa do nome dos autores; (b)também caracterizada a omissão ilícita da Administração Pública, pois não tomou qualquer providência para cessar o ilícito, sendo inaceitável de servidor público com cargo de chefia atitudes arbitrárias em face dos subordinados, motivadas por intolerância e preconceito; (c)a urbanidade é um dos deveres dos servidores públicos, cuja violação pode ensejar a prática do assédio moral; (d)as práticas sistemáticas constrangedoras, vexatórias, humilhantes e discriminatórias pelos superiores hierárquicos perduraram por considerável lapso de tempo, inclusive com comentários pejorativos e jocosos que permitiam identificá-los no contexto da pequena comunidade local e (e)o assédio moral pode ser compreendido como ações e práticas repetidas e dirigidas a um ou mais trabalhadores, de forma deliberada ou inconsciente, indesejáveis pela vítima, mas que causam ofensa e humilhação.

O caso da Apelação Cível 70065169690, Des. Carlos Eduardo Richinitti, 30.09.2015, tratou de hipótese de assédio moral horizontal, praticado por colegas, quando relotado na Secretaria de Saúde do Estado, eis que ao retornar à $5^{\text {a }}$ Coordenadoria de Saúde enfrentou problemas de aceitação por parte de alguns colegas, sendo realocado em setor diverso. Afirmou que passou por situações de isolamento e não disponibilização de material de trabalho. A análise do conteúdo da decisão permite firmar alguns entendimentos sobre o assédio moral: (a)sob a perspectiva doutrinária, trata-se de forma de coação social que se traduz pela repetição de condutas tendentes a expor a vítima a situações incômodas e humilhantes; (b)eventos isolados, desavenças esporádicas não se enquadram como assédio moral, pois o objetivo do assediador é envolver e fragilizar a vítima; (c)os atos de assédio moral podem ser praticados por colegas de igual hierarquia (assédio moral horizontal); (d)dentre as formas de agressão podem ser destacadas a recusa de comunicação direta, a vol.09, nº. 03, Rio de Janeiro, 2016. pp. 
desqualificação da vítima, seu isolamento, submetê-la a constrangimentos e provocar equívocos no desenvolvimento do trabalho; (e)ficou comprovado no caso o assédio moral por meio de gestos, comentários discriminatórios e isolamento do servidor público, bem como a conivência dos superiores hierárquicos e (f)o assédio moral também se configura por meio de omissão do Estado quando deixa de estabelecer diretrizes e regras, bem como fiscalizar os órgãos públicos de forma a proporcionar aos seus servidores condições materiais e psíquicas para o exercício de sua atividade.

Por fim, destaca-se o julgamento da Apelação Cível no 70061992020, Des. Miguel Ângelo da Silva, 25.11.2015, no qual servidor público da Câmara de Vereadores requereu o pagamento de indenização por danos morais, em virtude de assédio moral consistente na instauração de Sindicância Administrativa e expedição de portaria de suspensão do exercício das atividades funcionais, eis que caracterizada perseguição política. No entanto, manteve-se a sentença de improcedência sob o argumento de inexistência de prova sobre os fatos de perseguição política. Também ficou caracterizado o legítimo exercício do poder disciplinar, inclusive o afastamento do servidor público, na medida em que ao tomar conhecimento do exercício do poder disciplinar ofendeu superiores hierárquicos, inexistindo qualquer prática abusiva pela Administração Pública.

Os julgados citados remetem para questão fundamental: a necessidade de justificar a decisão sobre a caracterização ou não do assédio moral, com base no conjunto de indicações teóricas antes mencionadas. É comum compreender a ofensa aos direitos de personalidade do servidor público, oriunda do superior hierárquico ou não, como assédio moral, quando, conforme aludido, a figura debatida exige algumas especificidades como a repetitividade e reiteração da conduta (GENTILE, 2009, p. 37). Igualmente, nos casos de assédio moral é possível examinar a conduta e os danos causados tanto sob a perspectiva patrimonial, como extrapatrimonial, muito embora essa última espécie predomine nos precedentes. No entendimento de Maria Gentile, o "mobbing" pode determinar (a)danos biológicos, na medida em que a vítima do assédio sofre danos sobretudo na esfera psíquica ou psicossomática, compreendendo os componentes da boa saúde, seja física ou psíquica (GENTILE, 2009, p. 52); e (b)danos existenciais, pois em virtude do assédio moral o servidor pode manifestar alterações prejudiciais da vida cotidiana, como a impossibilidade de realizar atividades habituais relacionadas com a normal qualidade de vida ou modificações dos próprios hábitos de vida (GENTILE, 2009, p.56).

Constata-se nos casos citados, por óbvio apenas a título exemplificativo, o elemento comum presente no regime jurídico dos servidores públicos, a relação de subordinação e como vol.09, n. 03, Rio de Janeiro, 2016. pp. 
tal espécie de característica das relações de trabalho proporciona a utilização abusiva e ilegítima, o que remete para o tema da prevenção do assédio moral. As diversas indicações, construídas a partir da breve amostragem jurisprudencial, contribui para alterar práticas cotidianas da Administração Pública e, principalmente, desenvolver ações públicas voltadas para a prevenção.

\section{AÇões PÚBlicas de PREVENÇÃo AO ASSÉdio MORAL NA ADMINISTRAÇÃO PÚBLICA.}

Conforme já destacado, o assédio moral desenvolve-se a partir de um conjunto de fases sucessivas no tempo, segundo destacado por Maria Gentile, impondo-se neste tópico revisitálas para aprofundar o tema do caráter preventivo. A autora refere (GENTILE, 2009, p. 08-09) que (a) a primeira fase caracteriza-se pela individualização da vítima, pelo mais variados motivos, com ataques sistemáticos. Aqui são diversos fatores que contribuem em maior ou menor grau para desencadear o início do "mobbing", impondo-se desenvolver competências para identificar locais ou circunstâncias potencialmente capazes de funcionar como estopim. Na Administração Pública, assim como na iniciativa privada, existe o elemento da competição, por vezes retroalimentada pelo volume de serviço, mas não há comportamento padrão, pois ciúmes, cobranças, desavenças particulares, etc. são motivos determinantes de ações relacionadas com o assédio moral.

A (b) segunda fase caracteriza-se pelo desencadeamento do clima de tensão na relação de trabalho, sendo que se trata do início propriamente dito do assédio moral. Após a escolha da vítima, o servidor público assediador cria situações de dificuldades, incômodos, mal-estar ou aborrecimento, cuja consequência é alterar o ambiente no serviço público. Também se destaca a relevância de a Administração Pública, seja por servidores públicos de igual hierarquia da vítima, mas principalmente pelos superiores hierárquicos, ou instrumentos não exclusivamente institucionais, perceber a mudança no ambiente de trabalho, pois em determinadas situações o assédio moral cria e retroalimenta-se do ambiente de má qualidade no serviço público.

$\mathrm{Na}$ (c) terceira fase do assédio moral ocorre a manifestação dos primeiros sintomas psicossomáticos no servidor vítima e que interferem no desenvolvimento de suas atividades, seguida da (d) quarta fase também denominada de erros e abusos da Administração Pública, incapaz de compreender a situação e as verdadeiras causas que interferem no desenvolvimento das atividades do servidor. A vítima fica cada vez mais acuada em alguns casos e subjugada à situação de assédio. No entanto, o ente público adota procedimentos administrativos atrelados à lógica burocrática da estrutura hierárquica e disciplinar, com a instauração de sindicâncias e vol.09, n. 03, Rio de Janeiro, 2016. pp.

1314 
processos administrativos. Com efeito, na (e)quinta fase os sintomas psicossomáticos agravamse e determinam, como aduz Maria Gentile (GENTILE, 2009, p. 09), o afastamento do servidor, por período mais prolongados, do exercício de suas atribuições até culminar com a (f)sexta fase que é a exclusão do mundo do trabalho. Na Administração Pública pela completa ausência de instrumentos eficazes de identificar os casos de assédio, o processo culmina com exonerações ou aplicações de outras sanções disciplinares, inclusive de demissão do servidor público vítima do assédio moral.

É claro que tais fases não são estanques e absolutas, pois há grande variedade de condutas, conforme os próprios precedentes julgados pelos tribunais brasileiros revelam. Mas casos como o primeiro, julgado pelo STF, AI 807909, no qual o Presidente da Câmara de Vereadores, utilizando-se do poder hierárquico, colocou em situação de constrangimento determinado servidor público, não ocorre por acaso, mas há em geral um processo de continuidade desencadeado por diversos fatores. A ação de indenização por danos extrapatrimoniais não pode ser a única alternativa de tutela da vítima do assédio, inclusive porque atua "ex post". No entendimento de Maria Gentile cabe à Administração Pública desenvolver estratégias eficazes de proteção aos servidores públicos, com medidas de caráter preventivo: "Una strategia efficace di protezione contro il mobbing deve essere prevista 'a monte', in una logica di tipo preventivo." (GENTILE, 2009, p. 130).

\section{A Mudança de Paradigma na Responsabilidade do Estado.}

Os precedentes referidos do STF, STJ e TJRS indicam que muitos casos sobre assédio moral na Administração Pública são judicializados por meio de ações de indenização por danos morais e materiais contra o ente estatal. A partir do já desenvolvido no item 2 deste breve estudo, a constitucionalização da responsabilidade extracontratual do Estado é imprescindível não apenas para dotar de efetividade o instituto em casos de assédio moral, mas construir mecanismos de prevenção. O cidadão, assim como o agente público, é merecedor de dignidade e respeito. Portanto, a lógica do ente público não pode mais residir em vislumbrar o problema a partir de como encontrar mecanismos para agilizar os pagamentos por danos causados, inclusive considerando o sistema de controle fundado na lógica do precatório e das requisições de pequeno valor (artigo 100 da Constituição Federal). Levar a sério a responsabilidade do Estado representa, sob a perspectiva do artigo $1^{\circ}$, inciso III, CF, assumir a postura administrativa de laborar com a prevenção de danos, no caso, oriundos de assédio moral, sem que se possa falar em discricionariedades, pois a regra do artigo $7^{\circ}$, inciso XII, combinada com o artigo 39, $3^{\circ}, \mathrm{CF}$, é impositiva, cabe à Administração Pública exercer as competências 
administrativas no sentido de reduzir os riscos inerentes ao trabalho público por meio de normas de saúde, higiene e segurança.

\section{A Procedimentalização dos Poderes Administrativos.}

Após o exame de alguns casos julgados, vislumbra-se a incidência considerável da prática do assédio moral quando agentes públicos exercem poderes administrativos ou deixam de atuar quando deveriam fazê-lo, destacando-se na jurisprudência a ilegitimidade dos poderes hierárquico e disciplinar. Não é por outro motivo que Maria Gentile refere: "Secondo autorevole dottrina la prevenzione del mobbing può essere attuata soprattutto attraverso la procedimentelizzazione dell'esercizio dei poteri imprenditoriali; tale procedimentalizazione consente, infatti, di controllare il correto esercizio degli stessi poteri...” (GENTILE, 2009, p.131). Trata-se de atuar especialmente no âmbito do controle interno da própria Administração Pública, modificando-se a lógica de exercício das competências administrativas de modo a compreender as situações de vulnerabilidade funcional dos servidores públicos, expostos às práticas ilegítimas. Quando examinadas as fases do "mobbing" referiu-se que a quarta caracteriza-se pelos equívocos do poder público ao não perceber as causas da modificação no rendimento de servidores públicos. A procedimentalização aqui defendida exige não somente ampliar o nível de controle interno e sim modificar a qualidade do controle, com a qualificação dos agentes públicos responsáveis por controlar o ambiente de trabalho.

\section{Adotar Ações Públicas Específicas.}

Quando se menciona a necessidade de adotar ações públicas específicas, refere-se o pressuposto segundo o qual além dos campos jurídico-administrativos tradicionais, é relevante desenvolver competências administrativas de modo diverso e em outras esferas, sendo que as políticas públicas assumem papel fundamental na prevenção do assédio moral. Conforme já destacado em outro contexto, a expressão política pública é termo de múltiplos significados, oriunda de "policy", englobando programas de governo, decisões, produtos ou modelos, ou "processo de decisão, ou seja, o conjunto de decisões tomadas em um determinado marco temporal.” (OHLWEILER, 2010, p. 408). No entendimento de Pierre Lascoumes e Patrick le Galès, os trabalhos de política pública caracterizam-se por alguns elementos: observação precisa dos programas e das burocracias em ação, abordagem setorial, análise minuciosa dos atores e dos sistemas de ação, abordagem em termos de sequência de etapas, cada uma entendida como espaço de ação específica com seu sistema de atores, suas dinâmicas, seus 
paradoxos e tensão entre os trabalhos empíricos que descrevem a dinâmica das interações e a conceituação dos modelos que dão coerência à ação. (LASCOUMES e LE GALÈS, 2012, p. 44). Para desenvolver ações públicas de prevenção ao assédio moral, cabe ao Poder Público ultrapassar a lógica das instituições burocráticas e disseminar a completa e correta informação para os servidores públicos, não somente sobre o assédio moral, mas, sobretudo sobre organização administrativa do serviço público (GENTILE, 2009, p. 132).

\section{Autonomização do Servidor Público para que seja Protagonista das Ações Preventivas.}

Como mencionado, as ações públicas efetivas de prevenção ao assédio moral devem ultrapassar o esquema de centralização adotado de forma tradicional pela Administração Pública e institucionalizar rotinas de coordenação. Os servidores públicos devem receber formação específica sobre o tema em discussão, de modo a que a ação pública de prevenção resulte não apenas por meio de autoridades administrativas, mas coordenando todos os interessados.

\section{Desenvolver Mecanismos Institucionais com a Capacidade de Verificar Situações de Risco.}

Os precedentes aludidos neste breve estudo, bem como o entendimento doutrinário, indicam que o assédio moral não ocorre de forma abrupta no serviço público, mas possui um conjunto de fases que se sucedem no tempo e decorrem de alguns fatores específicos de cada Administração Pública. O importante em termos de ações públicas de prevenção é entender a configuração da vulnerabilidade funcional. A expressão vulnerabilidade relaciona-se com o fato de qualquer pessoa estar exposta a diversos riscos, motivo pelo qual necessita de maior proteção. Como aduz Mari del Carmen Barranco Avilés (BARRANCO AVILÉS, 2014, p. 18), as situações de vulnerabilidade afetam a capacidade dos cidadãos de enfrentarem determinadas acontecimentos, no caso, relacionados com a ofensiva do servidor público autor de práticas vexatórias, humilhantes, de submissão. A vulnerabilidade, assim, relaciona-se com (a)situações de riscos e (b) processos de discriminação, sendo que nas duas hipóteses, o olhar da Administração Pública volta-se para construir alternativas de perceber de forma adequada a situação e materializar ações de autonomizar os servidores públicos vítimas de assédio moral. Como refere Paolo Raciti, e fazendo as devidas adaptações para o tema aqui abordado, a vulnerabilidade exprime a ideia de fragilidade do servidor no âmbito do serviço público, 
submetido a situações de riscos responsáveis pelo abuso de poderes administrativos ou desvio de finalidade, exigindo-se da Administração Pública o dever do cuidado para com tais servidores, eis que "le persone vulnerabili sono quelle persone la cui autonomia e dignitá o integritá possono essere minacciate." (RACITI, 2015, p. 02). Com efeito, a gestão pública deve desenvolver mecanismos permanentes com a capacidade de monitorar a presença de fatores que criam os riscos da vulnerabilidade funcional no ambiente do serviço público.

\section{A Instituição de Comissões Paritárias.}

Dentro da lógica de ações públicas coordenadas, as comissões paritárias configuram estratégia profícua para a prevenção do assédio moral, bem como os devidos encaminhamentos quando recebe encaminhamento sobre tal prática. No entendimento de Maria Gentili "gli strumenti attraverso cui realizzare l'intera strategia di contrasto al mobbing sono degli organismi ad hoc, c.d. Comitati paritetici sul fenemoneo del mobbing, da instituire presso ciascuna amministrazione entro sessanta giorni dall'entrata in vigore del contrato." (GENTILE, 2009, p. 134-135). Desde que concebidas com a devida autonomia e munidas de estrutura e conhecimento sobre assédio moral, tais comissões são instrumentos relevantes para construir a cultura de prevenção, cujos componentes são oriundos da própria administração, mas também de entidades associativas e sindicais, cujas atribuições podem ser diversas (GENTILE, 2009, p. 136) como: a) recolher dados relativos aos aspectos qualitativos e quantitativos do fenômeno assédio moral, b)mapear e individualizar as causas das situações de vulnerabilidade funcional relacionadas com o assédio moral; c)formular propostas de prevenção e repressão, com os devidos encaminhamentos; d)elaborar sugestões de marcos regulatórios sobre assédio moral, não apenas no âmbito interno da administração, mas, para a construção de indicações normativas de maior amplitude; e)prestar contas anuais das atividades desenvolvidas; e f)colaborar no processo de formação funcional do quadro de servidores públicos, com relação à cultura de prevenção e gravidade do assédio moral.

\section{CONCLUSÃO.}

A responsabilidade extracontratual do Estado por assédio moral é tema cada vez mais discutido na doutrina e jurisprudência, mas é necessário, sobretudo, construir ações públicas de prevenção. Observa-se a importância de tratar a questão com este olhar do constitucionalismo, no qual os direitos fundamentais têm aplicação direta nas relações entre servidores públicos e 
Administração Pública, especialmente no exercício de competências administrativas relacionadas com a hierarquia e disciplina.

Exige constante processo de controle, não apenas interno, da própria Administração, mas do Poder Judiciário, ultrapassando-se vetustas teses de assegurar determinados campos de imunidade de poder. A constitucionalização tem essa consequência, com a onipresença da Constituição relativamente às ações administrativas, mas também na construção de deveres jurídicos, permitindo a identificação de omissões ilegítimas, no caso, capazes de violar direitos de personalidade dos servidores públicos. No campo do controle administrativo, sob a perspectiva constitucional de exercício das competências administrativas, impõe-se reforçar o controle interno, mas não apenas vocacionado para o controle a posteriori e sim de construir a cultura de políticas públicas com a capacidade de prevenir a ocorrência do assédio moral. Tal postura exige a construção de um autêntico ethos contra o assédio moral, a partir da unidade e da solidariedade entre os servidores públicos.

Conforme se constatou dos precedentes citados, a prática do assédio moral exige algumas especificidades, pois não se configura quando houver tão-somente conduta ou omissão e que violam a dignidade do servidor. Não que tais ilicitudes devam ser relegadas para segundo plano, ou incapazes de gerar o direito à indenização. Restrito ao objeto da responsabilidade do Estado, o assédio moral na Administração Pública deve ser visto com cuidado (hermenêutico), exigindo-se coerente motivação para indicar (justificar) que houve, por exemplo, procedimento objetivo e ilegítimo do agente público prolongado no tempo, voltado para causar dano à vítima, discriminando-a, humilhando-a, causando um dano. Tratase da importância de revolver a história institucional da própria figura do assédio moral no caso concreto.

As dificuldades de compreender a caracterização do assédio moral revelam a necessidade de observar algumas questões, como o conjunto de atribuições fixadas para cada cargo público. Urge reconhecer que não há discricionariedade do administrador para (re)organizar ao seu alvedrio tais atribuições, sob pena de abrir possibilidades concretas de decisões arbitrárias e do assédio moral. Como referido, o Constitucionalismo Contemporâneo é relevante para prevenir qualquer espécie de tentativa de olvidar a autonomia do Direito Administrativo, um Direito que deve ser marcado por decisões administrativas constitucionalmente legítimas.

Esse objetivo exige controlar as diversas prerrogativas da Administração Pública, sendo que a dignidade humana, como mencionado, também constitui condição de possibilidade para resgatar o mundo prático do Direito Administrativo, desde que compreendida como vol.09, n. 03, Rio de Janeiro, 2016. pp. 
indicação hermenêutica da experiência de construção democrática das relações entre servidores e Poder Público.

No entanto, não se deve albergar o entendimento da necessidade de construir o conceito de assédio moral fincado na exigência de um tempo fixo, de ação ou omissão prolongada por meses, sob pena de olvidar que o conjunto de atos reiterados adquire essa qualificação no caso, mantendo-se a integridade e coerência com as indicações construídas pela doutrina e jurisprudência. Aqui há um aspecto significativo explicitado na sentença proferida pelo Tribunale di Tempio Pausania: o assédio moral possui relação hermenêutica com a configuração de dano existencial causado ao servidor público vítima do "mobbing", exigindo-se repetição de ações ou omissões ilegítimas. A doutrina contribuiu para o debate, também referindo a necessidade de haver a identificação de conflito cotidiano no serviço público e que ao repetir-se configura o início do assédio moral, com consequências diretas ou indiretas no próprio desempenho da atividade funcional da vítima e até, por vezes, na exclusão do serviço público. Também é preciso cada vez mais desenvolver a concepção objetiva do assédio moral, para a finalidade de aplicar o $\S 6^{\circ}$ do artigo 37, CF, mesmo nos casos de omissão administrativa, não se exigindo do administrador a presença da intenção. Deve-se compreender a dimensão normativa da conduta administrativa praticada, a partir da perspectiva da dignidade do servidor público (artigo $1^{\circ}$, III, CF) e da obrigação de sua vida funcional ser tratada com consideração e respeito. Tal modo de vislumbrar a relação institucional é crucial para desenvolver ações públicas de caráter preventivo.

O assédio moral na Administração Pública, portanto, é capaz de determinar a obrigação de indenização dos danos causados ao servidor vítima de tais ações ou omissões ilegítimas, mas o número crescente de casos exige outro desafio, a necessidade de construir políticas públicas de prevenção, voltadas para garantir o ambiente não apenas de eficiência administrativa, mas de respeito, cuidado e liberdade. A alteração de paradigmas exige desenvolver as competências administrativas para criar um ambiente no serviço público não propício para situações de vulnerabilidade funcional relacionadas com o assédio moral. Com o auxílio de comissões paritárias, impõe-se definir condutas funcionais concretas incompatíveis, bem como aquilo que se circunscreve na órbita dos poderes hierárquico e disciplinar, considerando os diversos casos de responsabilidade extracontratual do Estado relacionados com tais prerrogativas. Configura-se tarefa difícil, mas decidida no rumo de materializar indicações constitucionais de dignidade humana e solidariedade no serviço público. 


\title{
MORAL HARASSMENT IN PUBLIC ADMINISTRATION: OF STATE RESPONSIBILITY FOR EFFECTIVENESS OF PREVENTIVE PUBLIC ACTIONS.
}

\begin{abstract}
This article investigates the extracontractual responsibility of the State for harassment when the victim of damage is the public official exposed to practices that extend through time and violate personal rights, just like the necessity public actions to prevent. The study uses the methodology of bibliography and jurisprudence study. The administrative competencies can only be exercised while respecting the autonomy of public officials. The fundamental rights and human dignity also determine the understanding of the duty to indemnify Public Administration and administrative actions to prevent, from the Democratic State of Right and a constitution phenomenon. Harassment is configures itself by illegitimate action or omission that violates the dignity and influence the everyday relations between public official $\mathrm{s}$ and hierarchical authorities. The harassment, horizontal or vertical, practiced within the public service determines the pay indemnity for patrimonial or moral damages, biological or existential. The Public Administration must act preventively by means of change the traditional paradigms and parity committees.
\end{abstract}

Keywords: Harassment; Public Administration; Human Dignity; Jurisprudence; Prevention.

\section{REFERÊNCIAS.}

BANDEIRA DE MELlo, Celso Antonio. Curso de Direito Administrativo. $26^{\text {a }}$ ed. São Paulo: Malheiros, 2009.

BARRANCO AVILÉS, Maria del Carmen. "Derechos Humanos y Vulnerabilidad. Los Exemplos del Sexismo y el Edadismo". In: Vulnerabilidad y Protección de los Derechos Humanos. Valencia: Tirant lo Blanch, 2014, p. 17-44.

BARROSO, Luís Roberto. A Dignidade Humana no Direito Constitucional Contemporâneo. A Construção de um Conceito Jurídico à Luz da Jurisprudência Mundial. $2^{a}$ reimp. Belo Horizonte: Fórum, 2013.

BAPTISTA, Patrícia. Transformações do Direito Administrativo. Rio de Janeiro: Renovar, 2003.

BINENBOJM, Gustavo. Uma Teoria do Direito Administrativo. $3^{\mathrm{a}}$ ed. Rio de Janeiro: Renovar, 2014.

BOVINO, Maria. Il Mobbing(Dalla Scienza ala Giurisprudenza), In: www.diritto.it/docs/34076-il mobbing, ISSN 1127-8579, publicado em 17/10/2012. Acesso em 02/03/2014.

BORGES, Alice Gonzales. "A Responsabilidade Civil do Estado à Luz do Código Civil: um toque de Direito Público", In: FREITAS, J. (Org.). Responsabilidade Civil do Estado. São vol.09, n. 03, Rio de Janeiro, 2016. pp. 
Paulo: Malheiros, 2006, p. 17-36.

CANAZI, Daniele M. Percorsi Ermeneutici di Filosofia del Diritto. Torino: G. Giappichelli Editore, 2012.

DWORKIN, Ronald. Justiça para Ouriços. Coimbra: Almedina, 2012.

A Justiça de Toga. São Paulo: Martins Fontes, 2010.

FREITAS, Juarez. O Controle dos Atos Administrativos e os Princípios Fundamentais. São Paulo: Malheiros Editores, $5^{\text {a }}$ ed., 2013.

"Responsabilidade Civil do Estado e o Princípio da Proporcionalidade: vedação de excesso e de inoperância", In: FREITAS, J. (Org.) Responsabilidade Civil do Estado. São Paulo: Malheiros, 2006, p. 170-171.

GADAMER, Hans-Georg. Verdad y Método. I. Fundamentos de una Hermenéutica Filosófica. $5^{\text {a }}$ ed. Salamanca: Ediciones Sígueme, 1993.

GARCIA DE ENTERRÍA, Eduardo. Curso de Derecho Administrativo, II. Madrid: Civitas, 1995.

GENTILE, Maria. Il Mobbing. Problemi e casi pratici nel lavoro pubblico. Milano: Giuffré Editore, 2009.

GONZÁLEZ PÉREZ, Jesús. La Dignidad de la Persona. 2ªed. Madrid: Civitas, 2011.

GUASTINI, Ricardo. "La Constitucionalización del Ordenamiento Jurídico: el caso italiano." In: M. CARBONELL, Neoconstitucionalismo(s). Madrid: Trotta, 2003.

GUTIERREZ, Ignácio Gutiérrez. Dignidad de la persona y derechos fundamentales. Madrid: Marcial Pons, 2005.

KANT, Immanuel. Fundamentación de la metafísica de las costumbres. Tradução de Manuel García Morente y Juan Miguel Palacios. Madrid: Editorial Tecnos, 2005.

LASCOUMES, Pierre e LE GALÈS, Patrick. Sociologia da Ação Pública. Maceió: Edufal, 2012.

MACHETE, Pedro. Estado de Direito Democrático e Administração Paritária. Coimbra: Almedina, 2007.

MARTINEZ, Gregorio. Percez-Barba. La Dignidad de la persona desde la Filosofia del Derecho. Dykinson: Madrid, 2003.

MASTINO, Casimiro. La Prima Sentenza Di Risarcimento Danni per Mobbing nel Pubblico Impiego. Disponível em: www.diritto.it/material/lavoro/mastino/html. Acesso em 02/03/2014.

MAURER, Hartmut. Direito Administrativo Geral. Barueri, SP: Manole, 2006.

MENDES, Gilmar. Ferreira. Direitos Fundamentais e Controle de Constitucionalidade. São Paulo: Celso Bastos Editor, 1998. 
MINASSA, Alexandre Pandolpho. Assédio Moral No âmbito da Administração Pública. Leme-SP: Habermann Editora, 2012.

MORAES, Maria. Celina. Bodin. Danos à Pessoa. Uma Leitura Civil-Constitucional dos Danos Morais. Rio de Janeiro: Renovar, 2009.

MUlhollan, Caitlin. Sampaio. A Responsabilidade Civil por Presunção de Causalidade. Rio de Janeiro: GZ Editora, 2009.

OHLWEILER, Leonel. Políticas Públicas. In: Dicionário de Filosofia Política. São Leopoldo: Editora Unisinos, 2010.

OTERO, Paulo. Legalidade e Administração Pública. O Sentido da Vinculação Administrativa à Juridicidade. Coimbra: Almedina, 2003.

RACITI, Paolo. "La Dimensioni dela Vulnerabilità e la Vita Buona: um'introduzione ai concetti.", In: Dialegesthai, http://mondodomani.org/dialegesthai/pr02.htm, 2009, p. 19-27. Acesso 03.10.2015.

ROCHA, Cármen Lúcia Antunes. Princípios Constitucionais dos Servidores Públicos. São Paulo: Saraiva, 1999.

SÁNCHEZ MÒRON, Miguel. Derecho de la Función Pública. 5aed. Madrid: Tecnos, 2008.

SARLET, Ingo. Dignidade da Pessoa Humana e Direitos Fundamentais na Constituição

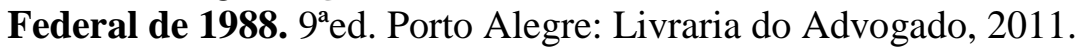

SEELMAN, Kurt. "Pessoa e Dignidade da Pessoa Humana na Filosofia de Hegel." In: Dimensões da Dignidade. Ensaios de Filosofia do Direito e Direito Constitucional, Ingo Wolfgang Sarlet(Org.). Porto Alegre: Livraria do Advogado, 2005, p. 45-60.

SEVERO, Sergio. Tratado da Responsabilidade Pública. São Paulo: Saraiva, 2009.

STEIN, Ernildo. Mundo Vivido: das vicissitudes e dos usos de um conceito da fenomenologia. Porto Alegre: Edipucrs, 2004.

Nas Proximidades da Antropologia. Ensaios e Conferências filosóficas. Ijuí: Editora Unijuí, 2003.

STRECK, Lenio Luiz. Hermenêutica Jurídica e(m) Crise; uma exploração hermenêutica da construção do Direito. $5^{\text {a }}$ ed. Porto Alegre: Livraria do Advogado Editora, 2004.

Hermenêutica Jurídica e(m)Crise; uma exploração hermenêutica da construção do Direito. $11^{\mathrm{a}}$ ed. Porto Alegre: Livraria do Advogado, 2014.

Jurisdição Constitucional e Decisão Jurídica. $3^{\text {a }}$ ed. São Paulo: Revista dos Tribunais, 2013, p. 341.

Verdade e Consenso. Constituição, Hermenêutica e Teorias Discursivas. $4^{\mathrm{a}}$ ed. $2^{\mathrm{a}}$ tiragem. São Paulo: Saraiva, 2012.

WOLF, Hans. J. Direito Administrativo. Vol. I. Lisboa: Fundação Calouste Gulbenkian, 2006. 
Trabalho enviado em 23 de dezembro de 2015.

Aceito em 23 de março de 2016. 